\title{
부산 세계개발원조총회 주요 성과 및 향후 과제
}

박 은 하 외교통상부 개발협력국 국장

\section{목 차}

1. 서론

2. 부산총회의 주요 성과와 의의

3. 향후 과제

4. 결어

첨부 : 부산총회 결과문서 국·영문본

\section{1. 서론}

제4차 세계개발원조총회1)가 11 월 29 일부터 12 월 1 일까지 사흘간 부산에서 개최되었다. 10 여명의 최고위급2) 및 100 여명의 장관급 인사를 포함, 160 여개 국가의 정부대표, 40 여개 국제기구 수장을 비롯한 70 여개 국제기구 대표, 시민사회, 의회, 민간분야 대표 등 총 3,000 여명이 참석하여 세계개 발원조총회 사상 최대 규모로 개최되었다.

참석자들은 부산총회 결과문서로 『효과적 개발협력을 위한 부산 파트너십(Busan Partnership for Effective Development Cooperation)』을 채택하고, 모든 개발주체를 포용하는 새로운 글로벌 개발 파트너십을 출범시켰다.

부산총회는 UN 새천년개발목표(MDGs) 달성 시한을 불과 4 년 앞두고 개발협력 분야에서 개최된 최대 규모·최고 권위의 행사로서, 개발도상국의 빈곤퇴치와 지속가능한 발전을 위한 국제사회의 노 력을 새로이 결집하는 역사적 전기를 마련한 것으로 평가받고 있다.

1) 부산 세계개발원조총회의 영문 회의명은 Fourth High Level Forum on Aid Effectiveness다. 로마(2003), 파리(2005), 아크라(2008)에 이어, 부산총회는 제4차 회의다.

2) 르완다 대통령, 에티오피아 총리, 유엔 사무총장, OECD 사무총장, 요르단 왕비, 미국 국무장관 등 
또한, 2010년 OECD 개발원조위원회(Development Assistance Committee) 가입 및 G20 서울 개 발 컨센서스(Seoul Development Consensus) ${ }^{3)}$ 채택 주도 등을 바탕으로, 이번 총회에서 정부는 단순 히 행사 장소를 제공하는 차원을 넘어 의제 설정, 결과문서 문안 협상 등 실질사항에서도 주도적인 역 할을 담당하였다. 이를 통해 글로벌 개발협력 커뮤니티에 의제 설정자(agenda-setter), 선진국과 개 도국 간 가교 국가로서의 우리의 영향력과 위상을 다시 한 번 각인시키는 계기가 된 것으로 평가된다.

이 글에서는 급변하고 있는 글로벌 개발 환경 속에서 개최된 부산총회의 주요 성과와 의의를 조망해 보고, 부산총회 이후 새로운 글로벌 파트너십 형성과 post-Busan 체제의 향후 과제를 살펴보고자 한다.

\section{2. 부산 세계개발원조총회 : 주요 성과와 의의}

\section{가. 개최 배경과 준비체제}

국제사회는 2002년 개발재원에 관한 몬테레이 컨센서스 채택 이후 개발원조의 질을 제고하기 위 한 노력을 지속해 왔다. 이는 효과적인 개발협력을 위해서는 개발원조의 양적 확대뿐만 아니라 질적 제고가 병행되어야 한다는 인식에 바탕을 두고 있다. 이러한 노력이 구체화 된 것이 바로 로마선언 (2003), 파리선언(2005), 아크라행동계획(2008)이다. 특히, 파리선언에서는 5대 원칙4)과 12 개의 지 표(목표 달성률 포함)를 설정하고, 동 원칙과 지표들을 2010년까지 이행키로 합의하였다.

\section{〈표 1〉 파리선언 - 5 대 원칙, 12 개 지표 및 달성 목표}

\begin{tabular}{|c|c|c|}
\hline 5대 원칙 & 12개 지표 & 2010년까지 달성 목표 \\
\hline $\begin{array}{l}\text { 주인의식 } \\
\text { (Ownership) }\end{array}$ & $\begin{array}{l}\text { 1. 수원국의 구체적인 개발실행전략 수립 } \\
\text { - 빈곤감축 전략을 포함한 국가발전전략을 지니고있는 국 } \\
\text { 가의 수 }\end{array}$ & 최소 $75 \%$ 이상 \\
\hline \multirow{3}{*}{$\begin{array}{l}\text { 원조일치 } \\
\text { (Alignment) }\end{array}$} & $\begin{array}{l}\text { 2. 신뢰할 수 있는 국가 시스템 } \\
\text { - 조달체계와 공공재정관리시스템(PFM)을 지니고 있는 국 } \\
\text { 가 수 }\end{array}$ & 최소 $50 \%$ 이상 \\
\hline & $\begin{array}{l}\text { 3. 원조자금의 국가 우선순위 배정 } \\
\text { - 국가예산에 반영된 정부부문에 지원된 원조 자금의 비율 }\end{array}$ & $85 \%$ 이상 \\
\hline & $\begin{array}{l}\text { 4. 조율된 수원국 역량 강화 노력 } \\
\text { - 수원국의 자체 개발전략과 일치하는 프로그램(공여국-수원국 }\end{array}$ & $50 \%$ 이상 \\
\hline
\end{tabular}

3) 다함께 성장을 위한 서울 개발 컨센서스(Seoul Development Consensus for Shared Growth)

4) 주인의식(Ownership), 원조일치(Alignment), 원조조화(Harmonization), 상호책임성(Mutual Accountability), 성과를 위 한 관리(Managing for Results) 


\begin{tabular}{|c|c|c|}
\hline \multirow[t]{6}{*}{ 5대 원칙 } & 12개 지표 & 2010년까지 달성 목표 \\
\hline & 공동마련)을 통해 역량개발을 지원하는 공여국가의 비율(\%) & \\
\hline & $\begin{array}{l}\text { 5. 국가 시스템의 활용 } \\
\text { - 수원국의 조달 시스템과 공공재정관리시스템을 활용한 공 } \\
\text { 여국의 수와 원조자금비율 }\end{array}$ & $\begin{array}{l}\text { - 공여국이 } 100 \% \text { 수원국 시 } \\
\text { 스템 활용 } \\
\text { - PFM시스템을 사용하지 않 } \\
\text { 는 자금비율 감축 }(1 / 3-2 / 3)\end{array}$ \\
\hline & $\begin{array}{l}\text { 6. 유사프로젝트 수행조직(PIU) 최소화를 통한 수원국의 역량 } \\
\text { 강화 } \\
\text { - 국별 분리 프로젝트 수행 건수 }\end{array}$ & $2 / 3$ 감축 \\
\hline & $\begin{array}{l}\text { 7. 원조의 예측가능성 제고 } \\
\text { - 합의된 일정에 따라 집행된 원조의 비율 }\end{array}$ & $75 \%$ 이상 \\
\hline & $\begin{array}{l}\text { 8. 언타이드화 } \\
\text { - 비구속성 양자간 원조의 비율 }\end{array}$ & 지속적 향상 \\
\hline \multirow{2}{*}{$\begin{array}{c}\text { 원조조화 } \\
\text { (Harmonization) }\end{array}$} & $\begin{array}{l}\text { 9. 공통의 합의와 절차 활용 } \\
\text { - 프로그램방식으로 제공된 원조의 비율 }\end{array}$ & $66 \%$ 이상 \\
\hline & $\begin{array}{l}\text { 10. 공동 분석 활용 } \\
\text { - 현지공동조사단과 국별 공동분석의 비율 }\end{array}$ & $\begin{array}{l}40 \% \text { 이상 } \\
66 \% \text { 이상 }\end{array}$ \\
\hline $\begin{array}{c}\text { 성과 관리 } \\
\text { (Managing for } \\
\text { Results) }\end{array}$ & $\begin{array}{l}\text { 11. 성과중심 계획 } \\
\text { - 투명하고 모니터링 가능한 성과측정계획을 지닌 국가 수 }\end{array}$ & $75 \%$ 이상 \\
\hline $\begin{array}{l}\text { 상호 책임성 } \\
\text { (Mutual } \\
\text { Accountability) }\end{array}$ & $\begin{array}{l}\text { 12. 상호 공동책무 } \\
\text { - 원조효과 지표 이행 정도를 공동으로 측정하는 수원국 수 }\end{array}$ & $100 \%$ \\
\hline
\end{tabular}

당초 부산총회는 이러한 원조효과성 제고를 위한 일련의 국제적 노력을 최종 점검하고, 평가하는 마지막 총회 성격으로 추진되었다. 하지만 부산총회를 준비하는 과정에서 원조효과성을 넘어, 보다 포괄적인 개발 이슈와 미래지향적인 의제를 논의하는 회의로 목적과 성격이 재정립되었다. 이러한 결정의 배경에는 몇 가지 요인이 작용했다.

첫째, 공적개발원조(ODA)는 개발협력의 중요한 부분이지만, 원조만으로는 개발도상국의 궁극적인 개발을 가져올 수 없다는 인식이 확산되었기 때문이다. 지난 60 여년간 선진국은 개도국에 수많은 재 원을 쏟아 부었지만 1971년 이후 최빈개도국의 지위에서 벗어난 국가는 3개국5)에 불과했다. 실제 개 발에 영향을 미치는 요인들을 고려하지 않고 원조효과성만을 논의하는 것은 분명히 한계가 있었다.

둘째, 2011년 파리선언 모니터링 결과 원조효과성이 개발성과에 중요하다는 사실은 확인됐지만, 파리선언이 지나치게 절차적이고 기술적인 측면에 중점을 두고 있는데 대한 반성과 성찰을 불러왔

5) 보츠와나, 카보베르데, 몰디브 
다. 원조효과성 성과를 측정하기 위해 개발된 지표들과 모니터링 체계는 개발원조를 어떻게 전달 (delivery)해야 하는지에 초점을 맞춤으로써 일반 국민이나 정책 결정자들의 관심과 참여를 저해하 고, 일부 기술 관료와 개발 전문가들의 전유물로 인식되는 부작용을 초래했다.

셋째, 다양한 개발주체의 등장과 글로벌 위기 확산에 따른 국제사회의 공동 대응과 협력 필요성이 어느 때보다도 절실해졌다. 전통적인 선진국-개도국간 개발협력을 넘어 개도국간 협력을 일컫는 남 남협력, 글로벌 펀드, NGOs, 민간재단의 개발협력 규모와 영향력이 커지면서 글로벌 원조체제는 복 잡, 다기화되었다. 개발협력 참여자 및 방식의 확대와 함께, 경제위기, 기후변화, 식량안보, 분쟁, 자 연재해 등 글로벌 위기가 확산되면서 기존 선진국 중심의 개발협력과 그 규범 체제의 실효성과 적실 성이 약화되었고, 다양한 개발협력 주체를 아우르면서 개발협력 활동의 효과성과 임팩트를 제고시키 는 것이 중요한 이슈로 부상하였다.

이러한 배경에서 부산총회는 그간의 원조효과성 이행성과를 최종 점검하고, 그 평가를 바탕으로 2015년 MDGs 목표 달성을 위해 모든 개발주체의 참여하에 원조와 개발에 대한 새로운 합의를 이끌 어내는 정치적 회의로 그 성격이 바뀌었다.

부산총회는 G20 정상회의와는 달리 주최국인 한국에게 의제 결정권이 주어져있지는 않다. 부산총 회 행사 및 실질사항 준비는 $\mathrm{OECD}$ 개발원조위원회 산하 원조효과작업반(Working Party on Aid Effectiveness)6)을 중심으로 이루어졌고, 우리나라는 동 작업반의 부의장직을 맡았다.

국내적으로는 의제와 결과문서 협상을 담당하는 외교부 개발협력국과 행사 준비를 담당하는 부산 총회 준비기획단 두 축을 중심으로 부산총회 준비에 임하였다. 또한, 정부는 의제설정 및 행사 준비 과정에서 국내 전문가들의 의견과 시각을 반영코자 '부산총회 민간자문위원회' 및 '행사 자문위원회' 를 구성하였으며, 의제선정 과정에서 시민사회와의 소통과 협력을 통해 시민사회의 의견을 적극적으 로 수렴하기 위해 노력했다.

\section{나. 회의 의제 및 주요 활동}

부산총회는 본회의 외에 다양한 포럼을 비롯해 50 여개의 부대행사와 참석국가 및 기관들의 홍보의 장인 지식과 혁신 나눔터(Knowledge and Innovation Space)가 회의 전 기간 중 개최되었다.

6) 원조효과작업반은 70 여명의 선진국, 개도국, 국제기구, 시민사회 대표로 구성된 협의체로, 분기별로 개최되는 원조효과 작업반 전체회의와 집행위원회를 통해 부산총회 의제 및 행사 준비를 논의하였고, 10 월 전체회의를 끝으로 공식적인 활 동을 종료하였다. 


\section{(1) 본회의}

부산총회 본회의는 크게 네 가지 파트로 나누어 볼 수 있다. 첫 번째 파트에서는 파리선언과 아크라 행동계획 이행성과를 바탕으로 미완의 과제에 대해 논의하고, 투명성, 결과중심, 분절화 이슈가 핵심 의 제로 다루어졌다. 둘째 파트에서는 변화하고 있는 글로벌 환경 속에서 다양한 개발주체와의 협력방안과 실제로 개발을 가져오는 요인에 대해 논의하였으며, 남남/삼각협력, 민관협력, 취약국, 기후변화 재원의 효과성 제고, 효과적인 제도 구축이 주요 의제로 다루어졌다. 세 번째 파트에서는 미래 개발협력 방향과 원칙을 설정하여 원조와 개발에 대한 새로운 합의를 이끌어 내고, 부산총회에서 합의된 사항을 이행하 기 위한 추진체제가 논의되었다. 마지막 파트에서는 결과문서를 채택하고 부산총회를 마무리 지었다.

부산총회 첫날은 파리선언/아크라행동계획의 이행성과를 검토하는 고위급 회의가 개최됐고, 공식 개막식은 둘째 날 열렸다. 그 이후 각료급 회의에서는 정부, 국제기구, 시민사회단체 등이 제출한 40 여개의 제안서를 바탕으로 투명성, 결과와 책무성, 분절화 관리, 남남협력, 민간분야, 분쟁과 취약, 기후변화 재원, 효과적 제도 등 총 8개의 대주제에 대한 발표가 이어졌다.

또한, 부산총회에서는 양성평등 및 여성의 역량 강화 이슈에 관한 특별 세션이 개최되어, 그동안 부수 적인 의제에 머물러 있었던 양성평등 이슈에 대한 국제사회의 관심과 정치적 지지를 끌어 모은 것으로 평 가된다. 11월 30일 개최된 양성평등 특별 세션에는 힐러리 미 국무장관, 미첼 바첼레트 UN Women 총재, 우리 여성가족부 장관 등 주요 고위급 인사가 참석하여 양성평등 및 여성의 역량강화를 통한 개발 촉진방 안을 논의하고, 그 결과문서로 '양성평등 및 개발에 관한 부산 공동 행동계획'을 채택하였다.

이밖에도, 정부는 우리의 개발경험을 바탕으로 본회의 '효과적인 제도 구축' 세션에 참여하여 과거 우리나라의 발전 경험에서 습득했던 교훈을 국제사회와 공유하였다.

\section{〈표 2〉부산총회 의제 및 일정}

\begin{tabular}{|c|c|c|c|}
\hline & 1일차 (11.29) & 2일차 (11.30) & 3일차 (12.1) \\
\hline \multirow{3}{*}{$\begin{array}{l}\text { 오 } \\
\text { 전 }\end{array}$} & $\begin{array}{l}\text { 전체회의 } \\
\text { “파리선언 이후의 진전사항” }\end{array}$ & 개막식 & $\begin{array}{l}\text { 본회의 (3) } \\
\text { “개발 효과 최대화 방안” } \\
\text { • 효과적인 제도 구축 } \\
\text { - 민간부문 }\end{array}$ \\
\hline & \multirow[b]{2}{*}{$\begin{array}{l}\text { 주제별 토의 (1) } \\
\text { “파리선언 및 아크라행동계획의 주 } \\
\text { 요 교훈” } \\
\text { - 주인의식과 책임성 } \\
\text { - 수원국 시스템 } \\
\text { - 원조 분절 }\end{array}$} & 양성평등 특별 세션 & \multirow{2}{*}{$\begin{array}{l}\text { 본회의 (4) } \\
\text { "원조와 개발에 관한 새로운 } \\
\text { 합의" }\end{array}$} \\
\hline & & $\begin{array}{l}\text { 본회의 (1) } \\
\text { “미완의 과제와 도전" } \\
\text { • 결과와 책임성 } \\
\text { • 투명성 } \\
\text { • 원조다양성과 분절화 }\end{array}$ & \\
\hline
\end{tabular}




\begin{tabular}{|c|c|c|c|}
\hline & 1일차 (11.29) & 2일차 (11.30) & 3일차 (12.1) \\
\hline & $\begin{array}{l}\text { - 투명성과 예측성 } \\
\text { - 원조와 개발성과 }\end{array}$ & & \\
\hline $\begin{array}{l}\text { 오 } \\
\text { 후 }\end{array}$ & $\begin{array}{l}\text { 주제별 토의 (2) } \\
\text { “원조효과성에서 개발효과성으로” } \\
\text { • 역량배양 및 지식공유 } \\
\text { - 인권기반 접근 } \\
\text { - 취약과 분쟁 } \\
\text { • 남남협력 및 삼각협력 } \\
\text { - 민관협력 }\end{array}$ & $\begin{array}{l}\text { 본회의 (2) } \\
\text { “변화하는 개발환경의 다양성과 기 } \\
\text { 회 확보" } \\
\text { • 남남협력 및 삼각협력 } \\
\text { - 취약국 } \\
\text { - 기후변화 재원 }\end{array}$ & \multirow[t]{2}{*}{$\begin{array}{l}\text { 폐막식 } \\
\text { 결과문서 채택 }\end{array}$} \\
\hline 기 & 의회 포럼/청소년 포럼 & 민간 포럼 & \\
\hline 타 & \multicolumn{3}{|c|}{ 지식과 혁신 나눔터 (KIS) \& 50여개 부대행사 } \\
\hline
\end{tabular}

\section{(2) 주요 포럼 및 부대행사}

부산총회는 과거 총회와는 다르게 정부 관계자뿐만 아니라 다양한 개발주체가 대거 참여함으로써 그 어느 때보다도 종합적이고 포괄적인 행사(multi-stakeholder event)로 치러졌다.

부산총회 준비과정에서 정부는 전 세계 시민사회, 의회, 민간기업 등 다양한 개발주체의 목소리를 담 기 위해 여러 가지 노력을 경주했다. 우선, 시민사회 참석자 수를 예전 80명 수준에서 300명으로 대폭 확대하였고, 민간분야와 의회 대표도 옵저버(observer)가 아닌 공식적인 개발 파트너로 초청했다. 또 한, 정부는 부산총회 논의에 대한 이들의 실질적인 참여와 기여를 제고하기 위해 BetterAid와 국제개 발협력시민사회포럼(KoFID) 공동 주관으로 개최된 시민사회 포럼(11.26-28)을 지원하고, 의회 포럼 (11.29), 청소년 포럼(11.29), 민간 포럼(11.30)을 주요 국제기구, 국내 관계기관과 공동으로 개최했다.

아울러, G20 개발의제 아웃리치 행사 및 $\mathrm{OECD}$ 개발전략 부대행사를 주관하여 부산총회와 여타 글로벌 포럼 및 개발 프로세스와의 연계를 모색하는데도 기여하였다.

\section{〈표 3〉부산총회 참석자 현황}

\begin{tabular}{|c|c|c|c|}
\hline \multicolumn{2}{|r|}{ 구 분 } & 제3차 가나/아크라 & 제4차 한국(부산 총회) \\
\hline \multirow{7}{*}{ 참석자 } & 총인원 & 약 1,700 & 약 3,000 \\
\hline & 정상급 & 3 & 10여명 \\
\hline & 국제기구 수장 & 15 & 40 \\
\hline & 장관급 인사 & 55 & 100 \\
\hline & 시민사회 대표 & 80 & 300 \\
\hline & 의회 관계자 (국회의원 포함) & 30 & 90 \\
\hline & 민간기업, 재단, 글로벌 펀드 등 & 30 & 100 \\
\hline
\end{tabular}


(3) 지식과 혁신 나눔터(Knowledge and Innovation Space: KIS)

'지식과 혁신 나눔터'에서는 성공적인 개발성과를 이끌어낸 개발협력 분야의 혁신적인 아이디어, 도구 및 이니셔티브 등이 담긴 95 개의 디지털 포스터가 전시되었다. 행사 참가자들은 개발협력 분야 의 새로운 지식과 혁신사례를 공유하고 상호의견을 교환하였다. 또한, 28 개의 미니토론과 14 개의 지 식공유 워크숍에서는 디지털 포스터에서 소개된 혁신적인 아이디어와 이니셔티브에 대한 심층적인 토론이 진행됐다.

\section{다. 결과문서의 주요 내용}

부산총회 참석자들은 결과문서로 『효과적 개발협력을 위한 부산 파트너십(Busan Partnership for Effective Development Cooperation)』을 채택함으로써, 효과적인 개발협력을 위한 새로운 글로벌 개발 파트너십을 출범시켰다.

부산총회 결과문서는 법적 구속력을 가진 문서는 아니지만, 부산총회에 참석한 다양한 개발주체의 효과적인 개발협력을 위한 공통의 정치적 의지와 구체적인 이행계획을 담았다. 결과문서 문안 협상 은 원조효과작업반 의장과 선진국, 개도국, 신흥국, 취약국가, 국제기구, 시민사회 대표로 구성된 17 명7)의 세르파(sherpa) 팀이 담당했다.

부산총회 결과문서는 크게 4 개 파트로 구성되어 있으며, 부산총회 의제와 밀접하게 연계되어 있다.

\section{(1) 정치적 서언}

서언 부분은 부산총회가 추구하는 정치적 메시지를 담았다. 모든 개발협력 활동의 4 대 기본원칙으 로 주인의식, 결과중심, 포괄적 개발 파트너십, 투명성 및 상호 책임성을 규정하고, 공통의 원칙하의 차별화된 공약 이행을 약속했다. 이는 전통적인 남북협력과 남남협력의 차별성 및 보완성을 인정하 면서, 모든 개발주체가 참여하는 새로운 개발협력 파트너십 형성을 통해 공동의 개발목표 달성을 위 해 함께 협력한다는 의지가 담겨 있다.

\section{(2) 원조효과성 심화 공약}

부산총회는 기존의 원조효과성 공약 이행이 미흡했다는 점을 인정하고, 미완의 과제에 대한 추가 이 행 공약에 합의했다. 특히, 개발흐름의 투명성 제고, 예측성 강화, 수원국 시스템 활용 측면에서 구체

7) 한국, 미국, 영국, 프랑스, 일본, EC, 방글라데시, 온두라스, 말리, 르완다, 중국, 남아공, 멕시코, 동티모르, UNDG, World Bank, Better Aid 
적인 공약과 목표 설정에 합의함으로써 원조효과성 핵심 원칙을 심화하는데 기여한 것으로 평가된다.

또한, 양성평등과 여성역량강화, 취약국가, 시민사회 및 의회의 역할 부문에서도 아크라행동계획 에 이어 실질적인 진전을 가져왔다.

\section{(3) 효과적인 개발을 위한 협력}

개발을 위해서는 원조만으로 부족하다는 인식하에, 전통적인 남북협력을 넘어 다양한 개발주체 및 협력방식을 인정하고, 이러한 개발활동의 효과성 제고를 위한 공약을 담았다. 특히, 남남/삼각협력 과 민간분야의 국제개발협력 분야에서의 역할을 인정하고, 반부패 및 불법재원 흐름 방지와 기후변 화 재원의 효과적인 활용을 강조했다.

\section{(4) 부산총회 이후 이행체제}

부산총회 합의사항 점검을 위한 포스트 부산 이행체제에 대한 기본적인 틀에 합의하였다. 무엇보다 수 원국 현장 중심의 이행체제로 추진하고, 글로벌 차원에서는 $\mathrm{OECD}$ 와 UNDP 간 협력 하에 가벼운 거버넌 스 체제(country heavy, global light)로 전환키로 합의했다. 또한, 모든 개발주체가 참여하는 새로운 글 로벌 파트너십(Global Partnership for Effective Development Cooperation)을 출범하여, 부산총회 합 의사항 이행을 점검키로 하고, 동 파트너십의 구체적인 운영방안은 2012 년 6 월까지 결정키로 했다.

\section{【부산선언 주요 내용】}

\begin{tabular}{|c|c|c|}
\hline 구분 & 주요 내용 & 세부내용 \\
\hline 서언 & $\begin{array}{l}\text { 새로운 글로벌 환경 조 } \\
\text { 망, 개발협력의 공통원 } \\
\text { 칙 및 행동 설정 }\end{array}$ & $\begin{array}{l}\text { - 공통 원칙 : } \boldsymbol{\Delta} \text { 주인의식, } \boldsymbol{\Delta} \text { 결과중심, } \boldsymbol{\Delta} \text { 포괄적 개발 파트너십, } \boldsymbol{\Delta} \text { 투명성 } \\
\text { 및 상호 책임성 } \\
\text { - 공통 행동 : } \boldsymbol{\Delta} \text { 개발 정책과 프로세스에서 민주적 주인의식 심화, } \boldsymbol{\Delta} \text { 구 } \\
\text { 체적이고, 지속가능한 개발성과를 위한 노력 강화, } \boldsymbol{\Lambda} \text { 남남/삼각협력에 } \\
\text { 대한 지원 확대, } \boldsymbol{\Delta} \text { 다양한 개발재원의 촉매적 역할 확보 } \\
\text { - 남북협력과 남남협력의 차별성 및 보완성 인정, 공통 원칙 및 차별화 } \\
\text { 된 행동 인정 } \\
\text { - 새로운 개발협력 파트너십 형성 및 이를 통한 유엔 새천년개발목표 } \\
\text { (MDG) 달성 의지 표명 }\end{array}$ \\
\hline \multirow{2}{*}{$\begin{array}{l}\text { 원조 } \\
\text { 효과성 } \\
\text { 심화 }\end{array}$} & $\begin{array}{l}\text { 주인의식, 결과 및 책 } \\
\text { 임성 강화 }\end{array}$ & $\begin{array}{l}\text { - 원조의 비구속화 가속화, 2012년 중간 점검 } \\
\text { - 수원국 시스템 활용 강화 } \\
\text { - 여성권한, 시민사회 및 의회 역할 강화 }\end{array}$ \\
\hline & 투명하고 책임있는 협력 & $\begin{array}{l}\text { - 공적자금 개발활동에 관한 전체 정보의 공개 및 표준화된 정보 공개 } \\
\text { 방식 활용, } \\
\text {-2013년까지 중장기 예측 가능성 제고 등 }\end{array}$ \\
\hline
\end{tabular}




\begin{tabular}{|c|c|c|}
\hline 구분 & 주요 내용 & 세부내용 \\
\hline & $\begin{array}{l}\text { 취약, 분쟁 상황에서의 } \\
\text { 지속 가능한 개발 촉진 }\end{array}$ & $\begin{array}{l}\text { - 평화구축 및 국가건설 목표 활용 } \\
\text { - 수원국 주도 취약성 평가 활용, 재원의 효과적 활용 및 결과중심 접 } \\
\text { 근을 통한 상호 신뢰 강화 }\end{array}$ \\
\hline & $\begin{array}{l}\text { 재난상황에서의 복원력 } \\
\text { 강화 및 취약성 감소 }\end{array}$ & - 충격을 견디는 인프라 구축 및 사회보호 체제 구축에 투자 \\
\hline \multirow{5}{*}{$\begin{array}{l}\text { 효과적인 } \\
\text { 개발을 } \\
\text { 위한 } \\
\text { 협력 }\end{array}$} & 효과적 제도 및 정책 & $\begin{array}{l}\text { - 수원국 주도하 개발 관련 핵심 국가기능 강화, 정책 제안.이행 지원 } \\
\text { 을 위한 정보 수집, 정책 개혁에 관한 지식 공유 등 }\end{array}$ \\
\hline & 남남협력 및 삼각협력 & $\begin{array}{l}\text { - 삼각협력의 확대, 남남협력 및 삼각협력의 성과 인정 } \\
\text { - 지식공유, 동료 학습 및 남남협력 내 조율 권장 }\end{array}$ \\
\hline & 민간분야 & $\begin{array}{l}\text { - 민간분야의 역할 중요성 인정 } \\
\text { - 민간의 성장.개발 관련 정책형성 참여, 민간역할을 지원하는 제도적 } \\
\text { 환경 마련 등 }\end{array}$ \\
\hline & 반부패 및 불법 자금 & $\begin{array}{l}\text { - 부패척결에 관한 공약 이행, 자금세탁, 조세회피 대처를 위한 장치 마 } \\
\text { 련 등 }\end{array}$ \\
\hline & 기후변화 재원 & $\begin{array}{l}\text { - 기후변화 대처 문제의 개발전략 포함, 기후변화재원 활용에 있어 원 } \\
\text { 조효과성 원칙 적용 권유 등 }\end{array}$ \\
\hline $\begin{array}{l}\text { Post- } \\
\text { Busan } \\
\text { 이행체제 }\end{array}$ & $\begin{array}{l}\text { 수원국 현장중심의 이 } \\
\text { 행과 가벼운 형태의 글 } \\
\text { 로벌 거버넌스 구축 }\end{array}$ & $\begin{array}{l}\text { - 2012년 중반까지 소수의 선택적 평가지표 개발 } \\
\text { • ‘효과적인 개발협력을 위한 글로벌 파트너십’ 출범 } \\
\text { - 2012년 6월까지 각료급 참여 대상, 각료급 참여 등을 포함한 실질 } \\
\text { 운영방안 합의 } \\
\text { - OECD 및 UNDP가 파트너십의 효과적 운영을 지원해 줄 것을 요청 }\end{array}$ \\
\hline
\end{tabular}

\section{라. 의의 및 평가}

2015년 MDGs 달성 목표 시한을 4년 정도 남겨둔 시점에서 개최된 이번 부산총회는 모든 개발주 체가 참여한 가운데 전례 없는 합의를 도출함으로써 국제개발협력뿐만 아니라 우리나라 개발협력 역 사에도 새로운 전기를 가져올 것으로 기대된다.

\section{(1) 국제개발협력분야 새로운 이정표 마련}

\section{가) 새로운 글로벌 파트너십 구축}

부산총회는 다양한 개발주체의 상호보완성과 차별성을 인정하면서, 공통의 원칙과 목표를 바탕으 로 모든 개발협력 주체가 참여하는 포용적 파트너십 구축에 합의함으로써 진정한 글로벌 파트너십을 구축하는데 기여했다. 
특히, 중국, 인도, 브라질 등 기존 $\mathrm{OECD}$ 중심의 개발논의에 유보적인 입장을 견지해 왔던 신흥국 들이 부산총회 결과문서 승인에 동참한 것은 이번 총회의 가장 큰 성과이자 진전으로 평가받고 있다.

\section{나) '개발효과성' 논의로 새로운 패러다임 창출}

기존 '원조' 중심의 논의를 '개발로 확대하고, 궁극적인 개발성과에 초점을 둔 개도국 중심의 맞춤형 개 발 지원 체제로 패러다임을 전환함으로써, 보다 포괄적인 개발효과성 담론을 촉발하는 계기를 만들었다.

이는 개발에 대한 포괄적인 접근방식을 채택하고 있는 G20 개발의제 등 주요 개발협력 이니셔티브 와의 연계 기반을 마련하고, 시너지를 확대할 수 있는 계기가 될 것으로 예상된다.

\section{다) $\mathrm{OECD}$ 중심에서 $\mathrm{OECD/UN}$ 연계 체제로 전환}

부산선언 이행 메커니즘으로 $\mathrm{OECD} \cdot \mathrm{UN}$ 의 합동 지원 체제가 출범하면서, 기존 $\mathrm{OECD}$ 중심의 이행 체제는 종료되었다. 특히, 양 글로벌 포럼의 장점과 비교우위를 살린 글로벌 지원체제 구축으로 $\mathrm{OECD}$ 의 선진 정책 노하우와 공여국에 대한 모니터링 체제를 지속적으로 활용하면서, UNDP의 개도 국 현장 사무소를 활용한 수원국 현장 중심의 이행체제를 지원하는 합동 체제가 출범하였다. 이는 2015년 MDGs 달성뿐만 아니라 post-MDG 프레임워크 구축 과정에서도 중요한 역할을 할 것으로 기 대된다.

\section{(2) 우리나라의 역량 및 위상 제고}

\section{가) 우리나라의 성공 스토리 확산 및 효과적 '가교 역할' 수행}

국내외 언론들은 '원조를 받던 나라'에서 '원조를 주는 나라'로 전환한 우리나라에서 부산총회가 개 최된 사실에 대해 큰 의미를 부여했다. 60 여년전 원조 물자의 하역지에서 세계 5 대 항구로 변모한 부산은 전 세계 개발도상국에게 희망의 상징이 되었다. 우리나라는 한국의 개발 성공에 입각해, 우리 나라 성공의 주요 동인이 되었던 효과적 제도 구축, 민간기업의 기여, 여성의 역량 강화 등을 부산 합의사항에 반영함으로써 우리 개발경험을 국제사회와 공유하고, 원조를 넘어선 개발효과성 의제를 도입하는데 주도적으로 참여했다.

또한, 부산총회 준비과정에서 남남협력의 보완적, 차별적 성격 인정과 글로벌 규범으로의 전환 필 요성 등을 설득함으로써 중국, 인도, 브라질 등 신흥국의 부산총회 참여 및 결과문서 승인을 이끌어 내는데 결정적인 역할을 수행했다. 국제 개발협력 커뮤니티에서는 우리나라가 주최국으로서 전통 공 여국과 신흥국 간 가교 역할을 훌륭히 수행한 것을 높이 평가하고 있다. 


\section{나) '글로벌 코리아' 위상 제고 및 지역 균형발전에 기여}

부산총회는 개발에 성공한 국가, 우리의 경험을 바탕으로 한 의제 설정 기여 등을 통해 개발분야 논의 주도국으로서 우리나라의 국제적 위상을 한층 높이는 계기를 마련하였다.

또한, 부산총회 개최에 따른 도시 브랜드 가치 제고 및 지역 경제 파급효과도 큰 것으로 나타났다. 부 산선언은 파리선언, 아크라행동계획과 같이 국제개발협력 커뮤니티에서 지속적으로 언급됨으로써 부산 의 도시 브랜드 가치를 높이는데 크게 기여할 것으로 예상된다. 부산발전연구원은 부산총회 개최에 따 른 경제적 파급효과가 5,237 억원으로, G20 회의 개최 도시 브랜드 홍보효과를 능가할 것으로 추정했다.

\section{3. 향후 과제}

지금까지 살펴보았듯이 부산총회는 국제개발협력 분야에서 의미 있는 성과를 많이 도출했다. 하지 만 부산총회 합의사항이 화려한 말잔치로 끝나지 않고 실제 행동으로 이어지기 위해서는 여러 과제 가 남아있다.

\section{(1) '부산 파트너십' 이행체제 구축}

부산총회 참석자들은 '부산 파트너십’의 세부 운영체계를 2012년 6월까지 결정하기로 합의했다. 모 든 개발주체가 참여하는 포용적인 개발 파트너십을 구축하기 위해서는 기존 $\mathrm{OECD}$ 산하의 원조효과작 업반을 대체하는 보다 포용적인 협의체 구축이 필요하고, 이를 위해서는 신흥국, 민간분야 등 다양한 개발주체의 참여를 유도할 수 있는 제도적 장치 마련과 UN 시스템과의 긴밀한 협력이 요구된다.

\section{(2) 신흥국과의 협력 강화}

부산 파트너십이 진정한 글로벌 파트너십이 되기 위해서는 신흥국의 참여가 무엇보다 긴요하다. 중국, 인도, 브라질 등 주요 신흥국들이 부산총회 결과문서를 승인했지만, '부산 파트너십' 참여 여부 에 대해서는 아직 조심스러운 입장을 갖고 있는 만큼, 이들과의 개발정책협의회 개최, 협력 MOU 체 결, 고위급 인사교류 등을 통한 상호 신뢰와 협력을 도모하고, '부산 파트너십'에 안정적으로 정착할 수 있도록 외교적 노력을 강화해 나가야 할 것이다. 


\section{(3) 우리 ODA 체제 선진화 노력 강화}

부산총회 개최국으로서 결과문서 공약에 대한 충실한 이행이 필수적이다. 특히, 원조 비구속화 확 대, 수원국 시스템 활용, 중기 지원계획 제공 등 주요 공약 이행을 위한 국내 원조 집행기관의 역량을 강화하고, 국내 원조체제의 분절화 방지를 통한 효율성 제고 노력을 강화해 나갈 필요가 있다.

또한, 이번 총회 개막식에서 대통령 기조연설을 통해 국제사회에 재천명한 2015년까지 ODA의 2 배 확대 공약을 착실히 이행해 나가고, 개발효과성 증대를 위한 역량 강화사업의 일환으로, 우리나라 개 발경험 공유 및 정책 자문사업의 내실화, 부산총회 계기에 채택된 '양성평등 및 개발에 관한 부산 공동 행동계획'에 대한 지원도 적극 추진할 필요가 있다.

\section{4. 결어}

부산총회는 역대 어느 회의 보다 다양한 개발주체와 고위급 인사의 참석으로 국제사회의 큰 관심 과 주목을 받았다. 그리고 그 기대에 걸맞은 성과를 거뒸다.

부산총회는 그간의 기술적인 원조효과성 논의에 매몰되지 않고, 공통의 개발목표와 원칙, 구체적인 이행방안에 대한 합의를 이끌어 냈다. 무엇보다 금번 합의가 기존 선진국-개도국 관계에서 벗어나 모 든 개발주체의 참여하에 이루어졌다는 것은 큰 의미가 있다. 부산총회에서 구축된 글로벌 파트너십은 국제개발협력의 새로운 출발점이자 패러다임의 전환을 의미한다. 앞으로의 과제는 모든 개발주체가 경험과 지혜를 모아 '부산 파트너십’이 차질 없이 이행될 수 있도록 최선의 노력을 다해 나가는 것이다.

이 과정에서 우리나라는 부산총회 주최국으로서 응분의 역할을 해 나가고자 한다. 우리의 개발경험과 2010년 G20 서울 개발 컨센서스 채택, 부산총회 준비 및 결과문서 협상과정에서 축적된 지혜와 경험을 잘 활용해 나간다면 포스트 부산체제 구축 과정에서도 주도적인 역할을 할 수 있을 것으로 기대된다.

특히, 재정위기로 선진국들이 주춤하고 있는 현 상황에서, 우리나라가 부산총회 결과 이행에 있어 리더십을 발휘할 경우 우리 개발협력 역량 강화 뿐 아니라 국제사회에서 진정한 개발 파트너로서 우 리의 위상을 제고하는데 크게 기여할 것이다. 


\section{첨부 1. 부산선언 영문본}

\section{BUSAN PARTNERSHIP FOR EFFECTIVE DEVELOPMENT CO-OPERATION FOURTH HIGH LEVEL FORUM ON AID EFFECTIVENESS, BUSAN, REPUBLIC OF KOREA, 29 NOVEMBER-1 DECEMBER 2011}

1. We, Heads of State, Ministers and representatives of developing and developed countries, heads of multilateral and bilateral institutions, representatives of different types of public, civil society, private, parliamentary, local and regional organisations meeting here in Busan, Republic of Korea, recognise that we are united by a new partnership that is broader and more inclusive than ever before, founded on shared principles, common goals and differential commitments for effective international development.

2. The nature, modalities and responsibilities that apply to South-South co-operation differ from those that apply to North-South co-operation. At the same time, we recognise that we are all part of a development agenda in which we participate on the basis of common goals and shared principles. In this context, we encourage increased efforts to support effective co-operation based on our specific country situations. The principles, commitments and actions agreed in the outcome document in Busan shall be the reference for South-South partners on a voluntary basis.

3. The world stands at a critical juncture in global development. Poverty and inequality remain the central challenge. The Millennium Declaration sets out our universal mandate for development and, with the target date for the Millennium Development Goals less than four years away, the urgency of achieving strong, shared and sustainable growth and decent work in developing countries is paramount. Moreover, the Declaration identifies that promoting human rights, democracy and good governance are an integral part of our development efforts. Nowhere are our development goals more urgent than in fragile and conflict-affected states. Political will is vital if these challenges are to be addressed.

4. As we reaffirm our development commitments, we realise that the world has changed profoundly since development co-operation began over 60 years ago. Economic, political, social and technological developments have revolutionised the world in which we live. Yet poverty, inequality and hunger persist. Eradicating poverty and tackling the global and regional challenges that have adverse effects on the citizens of developing countries are central to ensuring the achievement of the Millennium Development Goals and a more robust and resilient global 
economy for all. Our success depends on the results and impact of our joint efforts and investments as we address challenges such as health pandemics, climate change, economic downturns, food and fuel price crises, conflict, fragility and vulnerability to shocks and natural disasters.

5. We also have a more complex architecture for development co-operation, characterised by a greater number of state and non-state actors, as well as co-operation among countries at different stages in their development, many of them middle-income countries. South-South and triangular co-operation, new forms of public-private partnership, and other modalities and vehicles for development have become more prominent, complementing North-South forms of co-operation.

6. International development co-operation has achieved many positive results. When we met in Monterrey a decade ago, we recognised that increases in volumes of financing for development must be coupled with more effective action to generate sustainable and transparent results for all citizens. Our dialogue in Busan builds on the foundations laid by previous High Level Fora, which have been proven to remain relevant, and which have helped to improve the quality of development co-operation. Yet we recognise that progress has been uneven and neither fast nor far-reaching enough. We each reaffirm our respective commitments and will implement in full the actions to which we have already agreed.

7. We can and must improve and accelerate our efforts. We commit to modernise, deepen and broaden our co-operation, involving state and non-state actors that wish to shape an agenda that has until recently been dominated by a narrower group of development actors. In Busan, we forge a new global development partnership that embraces diversity and recognises the distinct roles that all stakeholders in co-operation can play to support development.

8. Our partnership is founded on a common set of principles that underpin all forms of development co-operation. At the same time, we recognise that the ways in which these principles are applied differ across countries at various stages of development, and among the different types of public and private stakeholders involved. Lessons should be shared by all who participate in development co-operation. We welcome the opportunities presented by diverse approaches to development co-operation, such as South-South co-operation, as well as the contribution of civil society organisations and private actors; we will work together to build on and learn from their achievements and innovations, recognising their unique characteristics and respective merits.

9. Sustainable development results are the end goal of our commitments to effective co-operation. While development co-operation is only part of the solution, it plays a 
catalytic and indispensable role in supporting poverty eradication, social protection, economic growth and sustainable development. We reaffirm our respective commitments to scale up development co-operation. More effective co-operation should not lead to a reduction in resources for development. Over time, we will aim to increase independence from aid, always taking into account the consequences for the poorest people and countries. In this process, it is essential to examine the interdependence and coherence of all public policies - not just development policies - to enable countries to make full use of the opportunities presented by international investment and trade, and to expand their domestic capital markets.

10. As we partner to increase and reinforce development results, we will take action to facilitate, leverage and strengthen the impact of diverse sources of finance to support sustainable and inclusive development, including taxation and domestic resource mobilisation, private investment, aid for trade, philanthropy, non-concessional public funding and climate change finance. At the same time, new financial instruments, investment options, technology and knowledge sharing, and public-private partnerships are called for.

\section{Shared principles to achieve common goals}

11. As we embrace the diversity that underpins our partnership and the catalytic role of development co-operation, we share common principles which - consistent with our agreed international commitments on human rights, decent work, gender equality, environmental sustainability and disability - form the foundation of our co-operation for effective development:

a) Ownership of development priorities by developing countries. Partnerships for development can only succeed if they are led by developing countries, implementing approaches that are tailored to country-specific situations and needs.

b) Focus on results. Our investments and efforts must have a lasting impact on eradicating poverty and reducing inequality, on sustainable development, and on enhancing developing countries' capacities, aligned with the priorities and policies set out by developing countries themselves.

c) Inclusive development partnerships. Openness, trust, and mutual respect and learning lie at the core of effective partnerships in support of development goals, recognising the different and complementary roles of all actors.

d) Transparency and accountability to each other. Mutual accountability and accountability to the intended beneficiaries of our co-operation, as well as to our respective citizens, organisations, constituents and shareholders, is critical 
to delivering results. Transparent practices form the basis for enhanced accountability.

12. These shared principles will guide our actions to:

a) Deepen, extend and operationalise the democratic ownership of development policies and processes.

b) Strengthen our efforts to achieve concrete and sustainable results. This involves better managing for results, monitoring, evaluating and communicating progress; as well as scaling up our support, strengthening national capacities and leveraging diverse resources and initiatives in support of development results.

c) Broaden support for South-South and triangular co-operation, helping to tailor these horizontal partnerships to a greater diversity of country contexts and needs.

d) Support developing countries in their efforts to facilitate, leverage and strengthen the impact of diverse forms of development finance and activities, ensuring that these diverse forms of co-operation have a catalytic effect on development.

13. We recognise the urgency with which these actions must be implemented. Beginning implementation now - or accelerating efforts where they are ongoing is essential if our renewed approach to partnership is to have the maximum possible impact on the realisation of the Millennium Development Goals by 2015, as well as on development results over the longer term. We will hold each other accountable for implementing our respective actions in developing countries and at the international level. As we focus on implementing our commitments at the country level, we will form a new, inclusive Global Partnership for Effective Development Co-operation to support implementation at the political level.

\section{Realising change: Complementary actions to reach common goals}

\section{Inclusion of new actors on the basis of shared principles and differential commitments}

14. Today's complex architecture for development co-operation has evolved from the North-South paradigm. Distinct from the traditional relationship between aid providers and recipients, developing nations and a number of emerging economies have become important providers of South-South development co-operation. They remain developing countries and still face poverty at home. As such, they remain eligible to benefit from development co-operation provided by others, yet they have increasingly taken upon themselves the responsibility to share experiences 
and co-operate with other developing countries. The Paris Declaration did not address the complexity of these new actors, while the Accra Agenda for Action recognised their importance and specificities. While North-South co-operation remains the main form of development co-operation, South-South co-operation continues to evolve, providing additional diversity of resources for development. At Busan, we now all form an integral part of a new and more inclusive development agenda, in which these actors participate on the basis of common goals, shared principles and differential commitments. On this same basis, we welcome the inclusion of civil society, the private sector and other actors.

\section{Improving the quality and effectiveness of development co-operation}

15. Progress has been made in advancing the aid effectiveness agenda, yet major challenges persist. Evidence has shown that - despite the challenges encountered in the implementation of our respective commitments - many of the principles underpinning the Paris Declaration on Aid Effectiveness and Accra Agenda for Action have contributed to higher quality, more transparent and effective development co-operation.

16. We will sustain our high-level political leadership to ensure that the commitments made here in Busan are implemented. Within this context, those of us that endorsed the mutually agreed actions set out in Paris and Accra will intensify our efforts to implement our respective commitments in full. A growing range of actors - including middle-income countries, partners of South-South and triangular co-operation and civil society organisations - have joined others to forge a broader, more inclusive agenda since Paris and Accra, embracing their respective and different commitments alongside shared principles.

17. Drawing on the evidence generated through periodic monitoring and the independent evaluation of the Paris Declaration, we will be guided by a focus on sustainable results that meet the priority needs of developing countries, and will make the urgently needed changes to improve the effectiveness of our partnerships for development.

\section{Ownership, results and accountability}

18. Together, we will increase our focus on development results. To this end:

a) Developing countries' efforts and plans to strengthen core institutions and policies will be supported through approaches that aim to manage - rather than avoid - risk, including through the development of joint risk management frameworks with providers of development co-operation. 
b) Where initiated by the developing country, transparent, country-led and country-level results frameworks and platforms will be adopted as a common tool among all concerned actors to assess performance based on a manageable number of output and outcome indicators drawn from the development priorities and goals of the developing country. Providers of development co-operation will minimise their use of additional frameworks, refraining from requesting the introduction of performance indicators that are not consistent with countries' national development strategies.

c) We will partner to implement a global Action Plan to enhance capacity for statistics to monitor progress, evaluate impact, ensure sound, results-focused public sector management, and highlight strategic issues for policy decisions.

d) As we deepen our efforts to ensure that mutual assessment reviews are in place in all developing countries, we encourage the active participation of all development co-operation actors in these processes.

e) Pursuant to the Accra Agenda for Action, we will accelerate our efforts to untie aid. We will, in 2012, review our plans to achieve this. In addition to increasing value for money, untying can present opportunities for local procurement, business development, employment and income generation in developing countries. We will improve the quality, consistency and transparency of reporting on the tying status of aid.

19. The use and strengthening of developing countries' systems remains central to our efforts to build effective institutions. We will build on our respective commitments set out in the Paris Declaration and Accra Agenda for Action to:

a) Use country systems as the default approach for development co-operation in support of activities managed by the public sector, working with and respecting the governance structures of both the provider of development co-operation and the developing country.

b) Assess jointly country systems using mutually agreed diagnostic tools. Based on the results of these assessments, providers of development co-operation will decide on the extent to which they can use country systems. Where the full use of country systems is not possible, the provider of development co-operation will state the reasons for non-use, and will discuss with government what would be required to move towards full use, including any necessary assistance or changes for the strengthening of systems. The use and strengthening of country systems should be placed within the overall context of national capacity development for sustainable outcomes.

20. We must accelerate our efforts to achieve gender equality and the empowerment 
of women through development programmes grounded in country priorities, recognising that gender equality and women's empowerment are critical to achieving development results. Reducing gender inequality is both an end in its own right and a prerequisite for sustainable and inclusive growth. As we redouble our efforts to implement existing commitments we will:

a) Accelerate and deepen efforts to collect, disseminate, harmonise and make full use of data disaggregated by sex to inform policy decisions and guide investments, ensuring in turn that public expenditures are targeted appropriately to benefit both women and men.

b) Integrate targets for gender equality and women's empowerment in accountability mechanisms, grounded in international and regional commitments.

c) Address gender equality and women's empowerment in all aspects of our development efforts, including peacebuilding and statebuilding.

21. Parliaments and local governments play critical roles in linking citizens with government, and in ensuring broad-based and democratic ownership of countries' development agendas. To facilitate their contribution, we will:

a) Accelerate and deepen the implementation of existing commitments to strengthen the role of parliaments in the oversight of development processes, including by supporting capacity development - backed by adequate resources and clear action plans.

b) Further support local governments to enable them to assume more fully their roles above and beyond service delivery, enhancing participation and accountability at the sub-national levels.

22. Civil society organisations (CSOs) play a vital role in enabling people to claim their rights, in promoting rights-based approaches, in shaping development policies and partnerships, and in overseeing their implementation. They also provide services in areas that are complementary to those provided by states. Recognising this, we will:

a) Implement fully our respective commitments to enable CSOs to exercise their roles as independent development actors, with a particular focus on an enabling environment, consistent with agreed international rights, that maximises the contributions of CSOs to development.

b) Encourage CSOs to implement practices that strengthen their accountability and their contribution to development effectiveness, guided by the Istanbul Principles and the International Framework for CSO Development Effectiveness. 


\section{Transparent and responsible co-operation}

23. We will work to improve the availability and public accessibility of information on development co-operation and other development resources, building on our respective commitments in this area. To this end, we will:

a) Make the full range of information on publicly funded development activities, their financing, terms and conditions, and contribution to development results, publicly available subject to legitimate concerns about commercially sensitive information.

b) Focus, at the country level, on establishing transparent public financial management and aid information management systems, and strengthen the capacities of all relevant stakeholders to make better use of this information in decision-making and to promote accountability.

c) Implement a common, open standard for electronic publication of timely, comprehensive and forward-looking information on resources provided through development co-operation, taking into account the statistical reporting of the OECD-DAC and the complementary efforts of the International Aid Transparency Initiative and others. This standard must meet the information needs of developing countries and non-state actors, consistent with national requirements. We will agree on this standard and publish our respective schedules to implement it by December 2012, with the aim of implementing it fully by December 2015.

24. We will also work to make development co-operation more predictable in its nature. To this end:

a) Those of us who committed, through the Accra Agenda for Action, to improve medium-term predictability will implement fully our commitments in this area, introducing reforms where needed. By 2013, they will provide available, regular, timely rolling three- to five-year indicative forward expenditure and/or implementation plans as agreed in Accra to all developing countries with which they co-operate. Other actors will aim to provide developing countries with timely and relevant information on their intentions with regard to future co-operation over the medium term.

25. We welcome the diversity of development co-operation actors. Developing countries will lead consultation and co-ordination efforts to manage this diversity at the country level, while providers of development assistance have a responsibility to reduce fragmentation and curb the proliferation of aid channels. We will ensure that our efforts to reduce fragmentation do not lead to a reduction in the volume and quality of resources available to support development. To this end:

a) We will, by 2013, make greater use of country-led co-ordination arrangements, including division of labour, as well as programme-based approaches, joint 
programming and delegated co-operation.

b) We will improve the coherence of our policies on multilateral institutions, global funds and programmes. We will make effective use of existing multilateral channels, focusing on those that are performing well. We will work to reduce the proliferation of these channels and will, by the end of 2012, agree on principles and guidelines to guide our joint efforts. As they continue to implement their respective commitments on aid effectiveness, multilateral organisations, global funds and programmes will strengthen their participation in co-ordination and mutual accountability mechanisms at the country, regional and global levels.

c) We will accelerate efforts to address the issue of countries that receive insufficient assistance, agreeing - by the end of 2012 - on principles that will guide our actions to address this challenge. These efforts will encompass all development co-operation flows.

d) Providers of development co-operation will deepen and accelerate efforts to address the problem of insufficient delegation of authority to their field staff. They will review all aspects of their operations, including delegation of financial authority, staffing, and roles and responsibilities in the design and implementation of development programmes; and they will implement measures that address the remaining bottlenecks.

\section{Promoting sustainable development in situations of conflict and fragility}

26. Fragile states are for the large part off-track to meet the Millennium Development Goals (MDGs). Achieving these goals will depend on our collective ability to understand the unique challenges facing fragile states, overcome these challenges, and promote foundations for lasting development. We welcome the New Deal developed by the International Dialogue on Peacebuilding and Statebuilding, including the g7+ group of fragile and conflict-affected states. Those of us who have endorsed the New Deal will pursue actions to implement it and, in doing so, will use:

a) The Peacebuilding and Statebuilding Goals (PSGs) - which prioritise legitimate politics, people's security, justice, economic foundations and revenues and fair services - as an important foundation to enable progress towards the MDGs to guide our work in fragile and conflict-affected states.

b) FOCUS - a new country-led and country-owned way of engaging in fragile states.

c) TRUST - a set of commitments to enhance transparency; manage risk to use country systems; strengthen national capacities; and improve the timeliness and predictability of aid - to achieve better results. 


\section{Partnering to strengthen resilience and reduce vulnerability in the face of adversity}

27. We must ensure that development strategies and programmes prioritise the building of resilience among people and societies at risk from shocks, especially in highly vulnerable settings such as small island developing states. Investing in resilience and risk reduction increases the value and sustainability of our development efforts. To this end:

a) Developing countries will lead in integrating resilience to shocks and measures for disaster management within their own policies and strategies.

b) Responding to the needs articulated by developing countries, we will work together to invest in shock resistant infrastructure and social protection systems for at-risk communities. In addition, we will increase the resources, planning and skills for disaster management at the national and regional levels.

\section{From effective aid to co-operation for effective development}

28. Aid is only part of the solution to development. It is now time to broaden our focus and attention from aid effectiveness to the challenges of effective development. This calls for a framework within which:

a) Development is driven by strong, sustainable and inclusive growth.

b) Governments' own revenues play a greater role in financing their development needs. In turn, governments are more accountable to their citizens for the development results they achieve.

c) Effective state and non-state institutions design and implement their own reforms and hold each other to account.

d) Developing countries increasingly integrate, both regionally and globally, creating economies of scale that will help them better compete in the global economy.

To this effect, we will rethink what aid should be spent on and how, in ways that are consistent with agreed international rights, norms and standards, so that aid catalyses development.

29. Effective institutions and policies are essential for sustainable development. Institutions fulfilling core state functions should, where necessary, be further strengthened, alongside the policies and practices of providers of development co-operation, to facilitate the leveraging of resources by developing countries. Developing countries will lead in efforts to strengthen these institutions, adapting to local context and differing stages of development. To this end, we will:

a) Support the implementation of institutional and policy changes led by developing countries, resulting in effective resource mobilisation and service delivery, including national and sub-national institutions, regional organisations, 
parliaments and civil society.

b) Assess country institutions, systems and capacity development needs, led by developing countries.

c) Support the development of improved evidence on institutional performance to inform policy formulation, implementation and accountability, led by developing countries.

d) Deepen our learning on the determinants of success for institutional reform, exchanging knowledge and experience at the regional and global levels.

\section{South-South and triangular co-operation for sustainable development}

30. The inputs to sustainable development extend well beyond financial co-operation to the knowledge and development experience of all actors and countries. South-South and triangular co-operation have the potential to transform developing countries' policies and approaches to service delivery by bringing effective, locally owned solutions that are appropriate to country contexts.

31. We recognise that many countries engaged in South-South co-operation both provide and receive diverse resources and expertise at the same time, and that this should enrich co-operation without affecting a country's eligibility to receive assistance from others. We will strengthen the sharing of knowledge and mutual learning by:

a) Scaling up - where appropriate - the use of triangular approaches to development co-operation.

b) Making fuller use of South-South and triangular co-operation, recognising the success of these approaches to date and the synergies they offer.

c) Encouraging the development of networks for knowledge exchange, peer learning and co-ordination among South-South co-operation actors as a means of facilitating access to important knowledge pools by developing countries.

d) Supporting efforts to strengthen local and national capacities to engage effectively in South-South and triangular co-operation.

\section{Private sector and development}

32. We recognise the central role of the private sector in advancing innovation, creating wealth, income and jobs, mobilising domestic resources and in turn contributing to poverty reduction. To this end, we will:

a) Engage with representative business associations, trade unions and others to improve the legal, regulatory and administrative environment for the development of private investment; and also to ensure a sound policy and 
regulatory environment for private sector development, increased foreign direct investment, public-private partnerships, the strengthening of value chains in an equitable manner and giving particular consideration to national and regional dimensions, and the scaling up of efforts in support of development goals.

b) Enable the participation of the private sector in the design and implementation of development policies and strategies to foster sustainable growth and poverty reduction.

c) Further develop innovative financial mechanisms to mobilise private finance for shared development goals.

d) Promote "aid for trade" as an engine of sustainable development, focusing on outcomes and impact, to build productive capacities, help address market failures, strengthen access to capital markets and to promote approaches that mitigate risk faced by private sector actors.

e) Invite representatives of the public and private sectors and related organisations to play an active role in exploring how to advance both development and business outcomes so that they are mutually reinforcing.

\section{Combating corruption and illicit flows}

33. Corruption is a plague that seriously undermines development globally, diverting resources that could be harnessed to finance development, damaging the quality of governance institutions, and threatening human security. It often fuels crime and contributes to conflict and fragility. We will intensify our joint efforts to fight corruption and illicit flows, consistent with the UN Convention Against Corruption and other agreements to which we are party, such as the OECD Anti-Bribery Convention. To this end, we will:

a) Implement fully our respective commitments to eradicate corruption, enforcing our laws and promoting a culture of zero tolerance for all corrupt practices. This includes efforts to improve fiscal transparency, strengthen independent enforcement mechanisms, and extend protection for whistleblowers.

b) Accelerate our individual efforts to combat illicit financial flows by strengthening anti money laundering measures, addressing tax evasion, and strengthening national and international policies, legal frameworks and institutional arrangements for the tracing, freezing and recovery of illegal assets. This includes ensuring enactment and implementation of laws and practices that facilitate effective international co-operation. 


\section{Climate change finance}

34. Global climate change finance is expected to increase substantially in the medium term. Recognising that this resource flow brings with it new opportunities and challenges, we will endeavour to promote coherence, transparency and predictability across our approaches for effective climate finance and broader development co-operation, including to:

a) Continue to support national climate change policy and planning as an integral part of developing countries' overall national development plans, and ensure that - where appropriate - these measures are financed, delivered and monitored through developing countries' systems in a transparent manner.

b) Continue to share lessons learned in development effectiveness with those entities engaged in climate activities and ensure that broader development co-operation is also informed by innovations in climate finance.

\section{The road ahead: Partnering for progress towards and beyond the MDGs}

35. We will hold each other accountable for making progress against the commitments and actions agreed in Busan, alongside those set out in the Paris Declaration on Aid Effectiveness and Accra Agenda for Action. To this end, we will:

a) At the level of individual developing countries, agree on frameworks based on national needs and priorities for monitoring progress and promoting mutual accountability in our efforts to improve the effectiveness of our co-operation and, in turn, development results. Developing countries will lead in the elaboration of such frameworks which, together with any indicators and targets agreed, will respond to their specific needs and will be grounded in their aid and development policies. The results of these exercises will be made public.

b) Agree, by June 2012, on a selective and relevant set of indicators and targets through which we will monitor progress on a rolling basis, supporting international and regional accountability for the implementation of our commitments. We will build on the initiatives led by developing countries and learn from existing international efforts to monitor aid effectiveness. We will review these arrangements in the context of the post-MDG framework. We will periodically publish the results of these exercises.

c) Support initiatives at the national and regional levels led by developing countries that strengthen capacities to monitor progress and evaluate the impact of efforts to improve development effectiveness.

36. We accept that the strengthening of our co-operation and the adherence to both common goals and differential commitments calls for continued high-level political 
support, as well as an inclusive space for dialogue, mutual learning and accountability at the global level. Regional organisations can and should play an important role in supporting implementation at the country level, and in linking country priorities with global efforts. The UN Development Cooperation Forum is also invited to play a role in consulting on the implementation of agreements reached in Busan. To this end, we will:

a) Establish a new, inclusive and representative Global Partnership for Effective Development Co-operation to support and ensure accountability for the implementation of commitments at the political level. This Partnership will offer an open platform that embraces diversity, providing a forum for the exchange of knowledge and the regular review of progress.

b) Agree, by June 2012, on light working arrangements for this Global Partnership, including its membership and opportunities for regular ministerial-level engagement that complements, and is undertaken in conjunction with, other for a.

c) Call on the Working Party on Aid Effectiveness (WP-EFF) to convene representatives of all countries and stakeholders endorsing this document with a view to reaching agreement on the working arrangements for the Global Partnership - and the indicators and channels through which global monitoring and accountability will be supported - in preparation for the phasing out of the WP-EFF and its associated structures in June 2012.

d) Invite the Organisation for Economic Co-operation and Development and the United Nations Development Programme to support the effective functioning of the Global Partnership, building on their collaboration to date and their respective mandates and areas of comparative advantage. 


\section{첨부 2. 부산선언 국문본}

(비공식 번역본)

\section{효과적인 개발협력을 위한 부산 파트너십}

1. 대한민국 부산에 모인 선진국 및 개발도상국의 국가 정상, 장관 및 대표들, 다자 및 양 자 기구의 대표들, 여러 유형의 공공, 민간, 시민사회, 국회 및 지역기구의 대표인 우리 는 효과적인 국제 개발을 위한 공통의 원칙과 목표하에 차별화된 이행을 바탕으로 그 어느 때보다 광범위하고 포괄적인 새로운 파트너십으로 단합하였음을 인식하고 있다.

2. 남남협력의 성격, 방식 및 책임은 남북협력과 다르다. 동시에 우리 모두는 공동의 목표 와 공통의 원칙에 기초한 개발 의제의 한 부분으로 참여한다는 것을 인정한다. 이러한 맥락에서, 우리는 국별 상황에 따라 효과적인 협력을 지원하는 노력을 제고할 것을 독 려한다. 부산에서 합의된 결과문서의 원칙, 약속과 행동은 자발적인 원칙하에 남남협력 참여주체의 참고가 될 것이다.

3. 전 세계는 지금 중대한 기로에 서 있다. 빈곤과 불평등은 여전히 핵심 과제로 남아 있다. 새천년선언(Millennium Declaration)은 보편적인 개발 과제들을 설정했으며, 새천년개발목 표(MDGs) 달성 시점이 불과 4년밖에 남지 않은 시점에서 개발도상국의 강하고, 함께하는, 지속가능한 성장과 양질의 일자리 확보를 시급히 달성해야 하는 상황에 처해 있다. 또한, 새천년선언은 인권, 민주주의와 선정(善政)이 개발을 위한 우리의 노력의 중요한 요소라고 정의한다. 취약국과 분쟁국에서 이러한 우리의 개발 목표를 달성하는 것은 더욱 시급한 문제이다. 이러한 도전과제들을 해결하기 위해서는 정치적 의지가 필수적이다.

4. 우리는 개발에 대한 의지를 재확인하면서, 60 여 년 전 개발협력이 시작된 이래 세계가 크 게 변화했음을 인지하고 있다. 경제적, 정치적, 사회적, 기술적 발전으로 세상이 획기적으 로 변했으나, 여전히 빈곤과 불평등, 기아 문제가 지속되고 있다. 새천년개발목표를 달성하 고 모두를 위해 보다 견실하고, 회복력 있는 세계 경제를 구축하기 위해서는 개발도상국 의 국민들에게 부정적인 영향을 끼치는 빈곤과 여타 범세계적, 지역적인 문제들이 반드시 해결되어야 한다. 우리의 성공은 질병, 기후 변화, 경기 침체, 식량 및 연료 가격의 위기, 분쟁, 취약성, 충격과 자연재해에 대한 취약성 등과 같은 문제에 대처하면서 우리 공동의 노력과 투자로 얻은 결과와 그 영향에 우리가 얼마나 관심을 기울이는가에 달려 있다.

5. 우리는 또한 보다 많은 국가 및 비국가 주체들, 다수의 중진국을 포함한 다양한 발전 단계에 있는 국가들 간의 협력을 포함한 보다 복잡한 개발협력 체계를 갖고 있다. 남 남 및 삼각협력, 새로운 형태의 민관협력, 여타 다른 형태와 수단으로 이루어지는 개발 
의 중요성이 커지면서 남북 협력을 보완하고 있다.

6. 국제개발협력은 그동안 많은 긍정적인 성과를 얻었다. 10년 전 몬테레이 회의에서 우리는 개발재원 증대와 함께, 모든 국민들을 위한 지속가능하고 투명한 결과를 얻을 수 있는 보 다 효과적인 행동이 필요함을 인식하였다. 부산총회 논의는 개발협력의 질 향상에 대한 기여가 입증된 지난 세계개발원조총회에서 얻은 성과에 기반을 두고 있다. 그러나 우리는 그 진전이 불균형적이고, 그 속도와 영향 측면에서 충분하지 않았음을 자각하고 있다. 우 리는 각자의 약속을 다시 확인하고, 이미 합의한 행동들을 충실히 이행할 것이다.

7. 우리는 우리의 노력을 개선하고, 보다 가속화할 수 있으며 또 그렇게 해야 한다. 우리는 최근까지 비교적 협소한 범위의 개발 주체들만이 참여했던 의제 설정 과정에 참여하기 를 희망하는 국가 및 비국가 주체들을 포용하면서, 우리의 협력을 발전, 심화, 확대하고 자 한다. 부산총회에서 우리는 다양성을 포용하고, 모든 주체들이 개발을 지원하는데 각 자의 독특한 역할이 있음을 인정하는 새로운 글로벌 개발 파트너십을 결성할 것이다.

8. 우리의 파트너십은 모든 형태의 개발협력을 위한 공통된 원칙들을 바탕으로 하며, 이 러한 원칙들이 적용되는 방식은 각기 다른 발전 단계에 있는 국가들에서, 그리고 이에 참여하는 민관 주체들의 유형에 따라 다르다는 점을 인정한다. 개발협력에 참여하는 모든 주체들이 얻은 교훈은 공유되어야 한다. 우리는 남남협력, 시민단체 및 민간 주체 들의 참여와 같은 다양한 개발협력 접근법에 따라 창출되는 새로운 기회들을 환영하 고, 그러한 개발주체들의 고유한 특징과 각각의 장점을 인정하며, 그들이 얻은 성과와 혁신을 배우기 위해 협력할 것이다.

9. 우리가 지향하는 효과적인 협력의 최종 목표는 지속가능한 개발 성과이다. 개발협력은 물론 해결책의 전부는 아니지만, 빈곤퇴치, 사회보장, 경제성장, 지속가능한 개발에 있 어 촉매적이며 불가결한 역할을 한다. 우리는 개발협력을 증진하기 위한 각자의 약속 을 재확인한다. 보다 효과적인 협력은 개발 재원의 감소로는 이어지지 않아야 한다. 앞 으로 우리는 최빈층과 최빈국에 미치는 영향을 고려하면서 원조에 대한 의존도를 줄여 가야 한다. 동 과정에서 단순히 개발 정책만이 아니라 전체 공공정책의 상호 의존성과 일관성을 필히 확인함으로써 모든 국가들이 국제 투자와 교역 및 국내 자본시장의 확 대에 따른 기회를 최대한 활용할 수 있도록 해야 한다.

10. 개발 성과를 증대하고 강화하기 위해 협력하면서 우리는 세금과 국내 재원, 민간 투 자, 무역을 위한 원조, 자선 활동, 양허성 공적 자금, 기후변화 재원 등 지속가능하며 포괄적인 개발에 기여하는 다양한 재원들의 효과를 활성화하고 강화하기 위한 조치 를 취할 것이다. 이와 동시에, 새로운 금융 수단, 투자 방식, 기술 및 지식의 공유, 민 관 협력이 조속히 마련될 필요가 있다. 


\section{공동의 목표를 달성하기 위한 공통 원칙}

11. 우리는 개발협력의 근간이 되는 다양성과 개발협력의 촉매적 역할을 수용하면서, 인 권, 양질의 일자리, 양성평등, 지속가능한 환경 및 장애에 관한 국제적 합의들을 바탕 으로, 효과적인 개발을 위한 협력의 토대를 형성하는 아래의 공통 원칙들을 공유한다.

a) 개발 우선과제에 대한 개발도상국들의 주인의식. 개발을 위한 파트너십은 개발도상국 들이 중심이 되어 국별 상황과 필요에 맞춘 접근법을 사용할 때만이 성공할 수 있다.

b) 결과 중심. 우리의 투자와 노력은 빈곤퇴치, 불평등 감소, 지속가능한 개발, 개발도 상국들의 역량에 지속적인 영향을 미쳐야 하며, 개발도상국들이 정한 우선과제 및 정책과 일치되도록 유지해야 한다.

c) 포용적인 개발 파트너십. 열린 태도, 신뢰, 상호 존중과 학습은 개발 목표를 달성하 기 위한 효과적인 파트너십의 핵심이며, 모든 개발 주체들의 차별적이면서도 보완 적인 역할을 인정한다.

d) 투명성과 서로에 대한 책무성. 상호 책무성과 협력의 수혜자들과 각자의 국민들, 기 관, 유권자 및 관련 주체에 대한 책무성은 매우 중요하다. 투명한 활동은 향상된 책 무성을 가져오는 근간이 된다.

12. 이러한 공통된 원칙들은 다음과 같은 우리의 행동을 이끌 것이다.

a) 개발 정책 및 프로세스의 민주적 주인의식을 심화, 확대, 운용한다.

b) 구체적이고 지속가능한 결과를 얻기 위한 노력을 강화한다. 이를 위해서는 결과 중 심의 관리 개선, 모니터링, 진전 상황 평가와 그러한 평가의 전달 뿐만 아니라 지원 규모 확대, 국가 역량 강화, 개발 성과를 가져오는 다양한 재원과 이니셔티브의 활 용이 필요하다.

c) 남남 및 삼각협력에 대한 지원을 확대하고, 이러한 수평적 파트너십이 개별 국가 상황과 필요에 맞추도록 지원한다.

d) 개발도상국들이 다양한 형태의 개발 재원과 활동이 갖는 영향을 증진, 활용, 강화하고, 이러한 다양한 형태의 개발협력 활동이 개발에 촉매 역할을 할 수 있도록 지원한다. 
13. 우리는 이러한 행동들이 조속히 이행되어야 함을 인식하고 있다. 우리의 새로운 파트 너십이 2015년까지 새천년개발목표를 달성하는데 있어 최대의 효과를 발휘하고, 장기 적인 개발 성과를 가져오기 위해서는 지금 이행하는 - 또는 현재 그러한 노력들이 진 행 중일 때는 그것을 가속화하는 - 것이 필수적이다. 우리는 개발도상국 현장과 국제 사회에서 각자의 행동을 이행하는데 책임감을 가질 것이다. 우리는 개발도상국 현장 에서 우리의 약속을 이행하는데 초점을 두고, 정치적 차원에서 이행을 지원하기 위해 새롭고, 포용적인 효과적인 개발협력을 위한 글로벌 파트너십을 구축할 것이다.

\section{변화의 실현 : 공동의 목표 실현을 위한 보완적인 행동 공통의 원칙과 차별화된 이행에 바탕을 둔 새로운 개발주체의 포용}

14. 오늘날의 복잡한 개발협력 체계는 남북협력의 패러다임에서부터 진화했다. 원조 공여국 과 수원국간 관계인 전통적인 남북협력과는 다르게, 개발도상국과 신흥국들은 남남협력 의 중요한 제공국이 되었다. 그들은 개발도상국의 지위를 유지하고 있고, 국내적으로 빈 곤 문제를 안고 있다. 이에 따라, 그들은 다른 국가들이 제공하는 개발협력의 혜택을 얻 을 수 있지만, 점차 다른 개발도상국들과 경험을 공유하고 협력하려는 책임을 지고 있 다. 파리선언은 이러한 새로운 개발주체등장에 따른 복잡성을 다루지 않았지만, 아크라 행동계획은 그들의 중요성과 특수성을 인정하였다. 남북협력은 개발협력의 주류로 남아 있지만, 남남협력은 지속적으로 진화하고 있고, 개발을 위한 다양한 추가 개발재원을 제 공하고 있다. 이제 부산에서 우리 모두는 이들 개발협력 주체들이 공동의 목표, 공통의 원칙과 차별화된 공약을 기반으로 참여하는 새롭고 보다 포용적인 개발 의제의 일부분 이 되었다. 동일한 맥락에서 시민사회, 민간분야와 다른 개발주체들의 참여를 환영한다.

\section{개발협력의 질과 효과성 개선}

15. 그동안 원조효과성 의제가 발전해 왔으나, 여전히 주요한 도전 과제들이 남아있다. 우 리는 각자의 약속을 이행하는 과정에서 문제들에 직면했음에도 불구하고, 원조효과성 에 관한 파리선언(Paris Declaration)과 아크라행동계획(Accra Agenda for Action)의 근간이 되는 여러 원칙들은 보다 높은 수준의, 투명하며, 효과적인 개발협력에 기여했 음이 입증되었다.

16. 우리는 이곳 부산총회에서 합의된 약속들이 이행되도록 우리의 고위급 정치적 리더십 을 유지할 것이다. 이러한 맥락에서, 파리와 아크라에서 합의된 행동들을 비준한 우리 당사자들은 각자의 약속을 충실히 이행하기 위한 노력을 배가할 것이다. 파리와 아크 라 이후 중진국, 남남/삼각협력 참여국과 시민사회 단체를 포함한 다양한 개발협력 주체들이 공통의 원칙을 바탕으로 각각의 차별화된 약속을 인정하면서, 보다 포괄적 이고, 포용적인 의제를 형성하는데 참여해 왔다. 
17. 우리는 파리선언의 주기적인 점검과 독립적인 평가를 통해 얻은 증거를 바탕으로, 개 발도상국의 우선적인 필요를 충족시키는 지속가능한 결과에 초점을 맞춰, 개발을 위 한 파트너십의 효과성을 개선하는데 필요한 시급한 변화들을 이루어갈 것이다.

\section{주인의식, 결과, 그리고 책무성}

18. 우리는 다함께 개발 성과에 더욱 주력할 것이다. 이를 위해,

a) 개발협력 제공자들과 함께 공동의 위기관리 프레임워크 개발 등을 통해 위기를 피하는 대신 - 관리하는 접근법을 통한 핵심 제도와 정책을 강화하려는 개발도상국 들의 노력과 계획을 지원할 것이다.

b) 개발도상국의 이니셔티브로 개발도상국이 설정한 개발 우선과제와 목표를 바탕으 로 적정 수의 산출, 성과 지표를 활용해 개발도상국 주도의 현장에서의 투명한 성 과 프레임워크와 플랫폼을 모든 관련 개발주체의 공동의 도구로 채택하고, 모든 관 련 주체들과 함께 성과를 평가할 것이다. 개발협력 제공자들은 개발도상국들에게 부가적인 프레임워크 적용을 최소화하고, 개발도상국의 개발전략과 일치되지 않은 성과 지표를 요구하지 않을 것이다.

c) 우리는 진전 상황을 점검하고, 영향을 평가하고, 공공부문이 성과 중심적으로 건전 하게 관리되도록 하고, 정책 결정을 위한 전략적 사안들의 규명을 용이하게 하는 통계 역량을 강화하기 위한 글로벌 행동계획의 이행에 협력할 것이다.

d) 우리는 모든 개발도상국에서 상호 평가 검토를 정착시키기 위한 노력을 배가하면 서, 모든 개발협력 주체들이 이러한 과정에 적극 참여하도록 독려한다.

e) 아크라행동계획과 관련해서, 우리는 비구속성 원조를 줄이는 노력을 가속화할 것이 다. 우리는 2012년에 이러한 비구속성 달성 계획을 점검할 것이다. 비구속성은 재 화의 가치를 높일 뿐만 아니라 개발도상국의 고용과 소득창출을 제고시킬 수 있다. 우리는 비구속성 원조 보고의 질, 지속성과 투명성을 개선할 것이다.

19. 수원국 시스템 사용과 강화는 효과적인 제도를 구축하려는 우리 노력의 중요한 부분 으로 남아있다. 이를 위해, 파리선언과 아크라행동계획을 바탕으로 다음 사항을 이행 할 것이다.

a) 개발협력 제공국과 개발도상국의 지배구조와 협력하고 존중하면서, 공적 분야에 지 원되는 개발협력의 기본 접근방식(default approach)으로 수원국 시스템을 활용한다. 
b) 상호 합의한 진단 도구를 활용해 수원국 시스템을 평가하고, 그 평가 결과를 바탕 으로 개발협력 제공자는 수원국 시스템 활용 범위를 결정한다. 수원국 시스템 전면 활용이 가능하지 않을 경우, 개발협력 제공자는 그 이유를 설명하고, 개선방안을 수원국 정부와 논의한다. 수원국 시스템 활용과 강화는 지속가능한 성과를 위한 국 가 개발역량의 전반적인 맥락에서 다루어져야 한다.

20. 우리는 개발 성과를 달성하는데 있어 양성평등과 여성의 역량강화가 필수불가결하다 는 점을 인식하고, 국별 우선과제에 따른 개발 프로그램을 통해 양성평등과 여성 역 량강화를 위한 노력을 가속화해야 한다. 양성 불평등의 감소는 그 자체로써 목적이자, 지속가능하고 포용적인 성장을 달성하기 위한 필수요건이다. 우리는 기존의 약속을 이행하기 위한 노력을 배가하면서 다음 사항을 이행할 것이다.

a) 성별 데이터의 수집, 배포, 조화 및 활용을 위한 노력을 가속화하고 심화함으로써 정책 결정에 활용하고 투자의 방향을 이끌며, 이를 통해 공공지출이 남성과 여성 모두에게 적절하게 배분되도록 한다.

b) 양성평등과 여성 역량강화 목표를 국제적 및 지역적 공약을 바탕으로 한 책무성 체계에 통합시킨다.

c) 평화구축 및 국가 재건 등을 포함한 개발 노력의 모든 측면에서 양성평등과 여성 역량강화 문제를 다룬다.

21. 의회와 지방 정부는 시민과 정부를 연계하고, 국가의 개발 의제에 대한 보편적이며 민주적인 주인의식을 보장하는데 있어 중요한 역할을 한다. 의회와 지방 정부의 기여 도를 높이기 위해 우리는 다음 사항을 이행할 것이다.

a) 적절한 재원과 명료한 행동계획을 통해 역량 개발을 지원하는 등 개발 과정을 감시 하는 의회의 역할을 강화할 수 있도록 기존의 약속 이행을 가속화하고 심화한다.

b) 지방 정부가 단순한 서비스 지원을 넘어 지방 단위에서 참여와 책무성을 높이고 그 역할을 충실히 수행할 수 있도록 지원을 강화한다.

22. 시민사회단체들은 국민들이 권리를 주장할 수 있도록 하고, 인권 중심의 접근을 활성 화하며, 개발 정책 및 새로운 파트너십을 형성하고, 그 이행과정을 감독하는 중요한 역할을 한다. 시민사회단체들은 또한 국가가 제공하는 서비스에 보완되는 영역에서 서비스를 제공한다. 이에 대한 인식을 바탕으로 우리는 다음 사항을 이행할 것이다. 
a) 우리들 기존 각자의 약속을 충실히 이행함으로써, 특히 우리의 합의된 국제 권리에 부 합하는 개발에 대한 시민사회단체의 기여를 최대화할 수 있는 환경을 구축하는데 초점 을 맞추어, 시민사회단체들이 독립적인 개발 주체로서 역할을 다 할 수 있도록 한다.

b) 시민사회단체들이, 이스탄불 원칙과 시민사회단체 개발효과성을 위한 국제 프레임 워크(International Framework for CSO Development Effectiveness)를 바탕으로, 개 발효과성에 관한 시민사회단체의 기여와 책무성을 강화하는 관행을 실천하도록 독 려한다.

\section{투명하고, 책임 있는 협력}

23. 우리는 기존 각자의 약속을 바탕으로 개발협력 및 기타 개발재원에 관한 정보 제공 및 접근성을 개선할 것이다. 이러한 목표를 달성하기 위해 우리는 다음 사항을 이행 할 것이다.

a) 상업적으로 민감한 정보에 대한 정당한 우려를 고려하여, 공적 자금, 계약 조건, 개 발 성과 기여도에 관한 모든 정보를 공개한다.

b) 수원국 현지에서 투명한 공공재정관리 및 원조정보관리 시스템을 구축하는데 집중 하고, 모든 주체의 역량을 강화하여 의사결정 과정에서 이러한 정보를 보다 잘 활 용하고 책무성을 높이도록 한다.

c) 개발협력을 통해 제공되는 재원들에 대한 시의적절하고 포괄적이며 미래 지향적인 정보에 대한 전자 공개를 위해 공통의 공개된 표준을 마련한다. 동 표준은 OECD-DAC 통계 보고 및 국제 원조 투명성 이니셔티브(International Aid Transparency Initiative)와 다른 보완적인 보고 체계를 고려하여 추진한다. 동 표준은 개발도상국 및 주요 비국가 주체들의 정보에 대한 필요를 충족시켜야 한다. 우리는 2012년 12 월까지 동 표준에 합의하고, 각자 동 표준의 시행 일정을 공개하고, 2015년 12월까 지 전면 이행을 목표로 추진한다.

24. 우리는 보다 예측가능한 개발협력을 위해 협력할 것이다. 이를 위해 다음 사항을 이 행할 것이다.

a) 아크라행동계획상의 재원의 중장기 예측성 개선과 관련하여 약속을 했던 당사자들 은 동 분야에서 각자의 약속을 충실히 이행할 것이며, 필요한 경우 개혁을 추진할 것이다. 이들은 2013년까지 수원국에게 정기적이며, 시의적절한 3-5년 연동 예산안 및/또는 아크라에서 합의된 사항의 이행 계획을 제공할 것이다. 여타 개발주체들은 개발도상국들에게 향후의 중기 협력과 관련하여 시의적절한 방식으로 자신들의 의 
도에 관한 정보를 제공하기 위해 노력할 것이다.

25. 우리는 개발협력 주체들의 다양성을 환영한다. 개발도상국들은 현장에서 이러한 다양 성을 관리하기 위한 협의와 조정을 주도하고, 개발협력 제공자들은 분절화를 줄이고 원조 채널의 확산을 방지할 책임이 있다. 우리는 분절화를 줄이기 위한 노력으로 인 해 특정 국가에 대한 개발지원 재원이 감소하지 않도록 할 것이다. 동 목표 달성을 위해 우리는 다음 사항을 이행할 것이다.

a) 우리는 2013년까지 분업, 프로그램 중심의 접근, 공동 프로그램 및 위임협력 (delegated cooperation) 등 수원국 주도의 조정 제도를 보다 적극적으로 활용할 것이다.

b) 우리는 다자기구, 글로벌 펀드 및 프로그램에 대한 정책적 일관성을 제고할 것이다. 우리는 성과가 높은 기존의 다자협력 채널을 효과적으로 활용할 것이다. 우리는 2012년 말까지 공동의 노력을 위한 원칙과 가이드라인에 합의함으로써 이러한 다 자협력 채널의 확산을 조절하기 위해 노력할 것이다. 다자기구, 글로벌 펀드 및 프 로그램은 원조효과성에 대한 각자의 약속을 지속적으로 이행하면서, 수원국과 지역 및 국제적 차원에서 조정과 상호 책무성 체제에 대한 참여를 강화해 나갈 것이다.

c) 우리는 불충분한 지원을 받는 국가들의 문제를 해결하기 위한 노력을 가속화할 것 이다. 이를 위해 2012년 말까지 동 문제의 해결을 위한 우리의 행동 방향을 설정할 수 있는 원칙들에 합의할 것이다. 여기에는 모든 개발재원이 포함될 것이다.

d) 개발협력 제공자들은 현장 직원들에게 불충분한 권한이 위임되는 문제를 해결하기 위한 노력을 심화하고 가속화할 것이다. 개발협력 제공자들은 개발 프로그램의 기 획과 이행에서 재정 권한, 직원 채용, 역할 및 책임의 위임을 포함한 운영의 모든 측면을 검토하고, 남아 있는 장애를 해결하기 위한 조치를 시행할 것이다.

분쟁 및 취약한 상황에서 지속가능한 개발의 증진

26. 취약국들은 대체로 새천년개발목표의 달성에서 벗어나 있다. 새천년개발목표의 달성 은 취약국들이 직면하고 있는 고유한 문제들을 이해하고, 그러한 문제들을 극복하고 지속적인 개발을 위한 기반을 다지는 우리 공동의 역량에 달려 있다. 우리는 취약과 분쟁국가로 구성된 $\mathrm{G} 7+$ 국가가 참여한 평화구축 및 국가재건에 관한 국제대화 (International Dialogue on Peacebuilding and Statebuilding)에서 구축된 뉴딜(New Deal)을 환영한다. 뉴딜을 승인한 주체들은 이를 이행하기 위해 노력할 것이며, 이 과 정에서 우리는 다음 사항을 이행할 것이다.

a) 평화구축 및 국가재건 목표(Peacebuilidng and Statebuilding Goals) - 적법한 정치, 
치안, 정의, 경제적 기반, 세입과 공정한 서비스에 우선순위 부여 - 를 취약국가 및 분쟁국가에서 새천년개발목표 달성을 가능하게 하는 중요한 근거로 활용한다.

b) 취약국가에서 수원국이 주인의식을 갖고 주도하는 새로운 협력방식에 중점을 둔다.

c) 보다 나은 성과를 위해 투명성 개선, 수원국 시스템 활용에 따른 위험관리, 국가 역 량배양, 원조의 시의 적절성과 예측성 제고 약속에 대한 신뢰를 구축한다.

역경에 처한 상황에서 취약성을 줄이고 복원력을 강화하기 위한 파트너십

27. 우리는 특히 소규모의 저개발 도서국처럼 극도로 취약한 상황에서, 개발 전략과 프로 그램이 충격(shocks)으로 인해 위기에 처한 사람들과 사회의 복원력을 구축하는 일을 우선과제로 삼도록 해야 한다. 복원력과 위기 감소에 대한 투자는 개발 노력의 가치 와 지속가능성을 높인다. 이를 위해 우리는 다음 사항을 이행할 것이다.

a) 개발도상국들은 충격에 대한 복원력과 재난관리 조치를 수원국의 정책과 전략에 주 도적으로 통합할 것이다.

b) 개발도상국들이 명시한 필요에 따라 우리는 충격방지 인프라와 위험에 노출된 공 동체를 위한 사회보호시스템에 투자하기 위해 협력할 것이다. 또한, 우리는 수원국 현지 및 지역 차원에서 재난관리를 위한 자원, 계획, 기술 제공을 증가시킬 것이다.

\section{효과적인 원조에서 효과적인 개발을 위한 협력으로}

28. 원조는 개발문제 해결방안의 일부분일 뿐이다. 지금은 우리의 초점과 관심을 원조효 과성에서 효과적인 개발의 문제로 확대할 시점이다. 여기에는 개발을 위한 프레임워 크가 요구된다. 동 프레임워크 안에는 다음 사항이 포함되어야 한다.

a) 강력하고 지속가능하며 포용적인 성장이 개발을 견인한다.

b) 자국의 개발에 필요한 재원을 동원하는데 있어 정부의 자체 재원이 보다 많은 역 할을 담당한다. 이로써 정부가 달성한 개발 성과에 대해 국민들에게 책임을 질 수 있게 된다.

c) 효과적인 국가 및 비국가 기관들은 자체적인 개혁을 설계 및 실행하고 상호 책무성 을 갖는다. 
d) 개발도상국들은 지역적 및 지구적으로 점차 통합되면서 세계경제에서 보다 나은 경쟁우위를 확보할 수 있는 규모의 경제를 창출한다.

이를 위해, 우리는 합의된 국제적 권리와 규범에 따라 원조가 사용되는 방법과 대상을 재 검토함으로써 원조가 개발의 촉매 역할을 하도록 할 것이다.

29. 효과적인 제도 및 정책은 지속가능한 발전을 위해 중요하다. 필요할 경우 핵심적인 국가 기능을 이행하는 제도는 강화해야 하며, 이와 함께 개발협력 제공자들의 정책과 관행이 개발도상국에 의해 재원을 활용할 수 있도록 해야 한다. 개발도상국은 이러한 제도를 현지 상황과 서로 다른 발전 단계에 맞게 강화할 것이다. 이를 위해, 우리는 다음 사항을 이행할 것이다.

a) 개발도상국 주도로 제도 및 정책 변화가 이루어지도록 지원하고, 이를 통해 정부, 지방 제도, 지역기구, 의회, 시민사회를 포함한 효과적인 재원을 동원하고 서비스를 제공하도록 한다.

b) 개발도상국 주도로 국별 제도, 시스템, 역량 개발을 평가한다.

c) 개발도상국 주도로 제도 성과에 대한 개선된 근거 개발을 지원하여 정책 입안, 이 행 및 책임을 갖게 한다.

d) 지역 및 글로벌 차원에서 상호 지식과 경험을 공유하여 제도개혁의 성공요인의 습 득을 심화한다.

\section{지속가능한 개발을 위한 남남 및 삼각협력}

30. 지속가능한 개발에 대한 논의는 재정적 협력을 훨씬 넘어서서 모든 개발주체 및 국가 의 지식과 개발 경험으로까지 확장된다. 특히 남남 및 삼각협력은 각국의 상황에 적 합하고 효과적이며 지역적인 주인의식을 갖는 해결책을 실현함으로써 개발도상국들의 서비스 전달 정책과 접근법을 바꿀 수 있는 잠재력이 있다.

31. 우리는 남남협력에 참여하는 많은 국가들이 다양한 재원과 전문성을 동시에 주고 받는 점 을 인식하며, 이것이 협력을 증진하되 해당국이 다른 재원을 지원받을 가능성을 저해하지 않아야 한다고 믿는다. 우리는 다음 사항을 통해 지식과 상호 학습을 강화할 것이다.

a) 적절한 경우, 개발협력에 대한 삼각접근의 사용을 증진한다.

b) 남남 및 삼각협력 접근법이 지금까지 거둔 성공을 인정하고 이를 보다 적극 활용한다. 
c) 개발도상국들이 축적한 중요한 지식의 보고(knowledge pools)에 대한 접근성을 증 진하는 수단으로써 남남협력 주체들 간의 지식 교환, 상호 학습 및 협력 네트워크 의 개발을 독려한다.

d) 남남/삼각협력에 효과적으로 참여하기 위한 지방, 국가 역량강화를 지원한다.

\section{민간부문과 개발}

32. 우리는 혁신, 부, 소득, 일자리 창출, 국내 자원의 활용에 있어 민간부문이 핵심적인 역 할을 한다는 사실을 인정한다. 동 목표를 위해서 우리는 다음 사항을 이행할 것이다.

a) 재계의 대표적인 조직들, 노조 및 여타 관련 주체와 협력하여 민간투자 개발을 위 한 법적, 규제, 행정 환경을 개선하고, 외국인직접투자 및 민관 파트너십의 증대, 평 등한 방식, 특히, 국가 및 지역적 차원을 고려한 가치 사슬(value chain) 강화, 개발 목표 지원 노력의 강화를 위한 건전한 정책과 규제 환경을 구축한다.

b) 지속가능한 성장을 촉진하는 개발 정책 및 전략을 기획하고 구현하는 과정에 민간 부문의 참여를 가능하게 한다.

c) 공동의 개발 목표를 달성하는데 민간 재원을 동원할 수 있는 혁신적인 금융체계를 더욱 발전시킨다.

d) 성과와 영향에 중점을 둔 지속가능한 개발의 동력으로써 "무역을 위한 원조"를 증 진하여, 시장의 실패에 대처하고, 자본시장에 대한 접근성을 강화하며, 민간부문 주 체들이 직면한 위기를 완화시킬 수 있는 접근법을 증진한다.

e) 민관부문 및 관련 단체의 대표들이 개발과 사업 성과를 동시에 증진하는 방법을 적 극적으로 모색함으로써 서로에게 도움이 되도록 한다.

\section{부패와 불법적 흐름의 척결}

33. 부패는 글로벌 개발을 심각하게 저해하고, 개발 재원으로 이용될 수 있는 자원을 분산 시키며, 거버넌스 기관의 질을 저해하고, 인간 안보를 위협하는 병폐이다. 부패는 범죄 를 양산하며 분쟁과 취약성으로 이어지는 경우가 많다. 우리는 유엔 반부패협약(UN Convention Against Corruption) 및 $\mathrm{OECD}$ 뇌물방지협약(Anti-Bribery Convention)과 같은 협약들을 바탕으로 부패와 불법적 흐름을 척결하기 위한 공동의 노력을 강화할 것이다. 동 목표를 달성하기 위해 우리는 다음 사항을 이행할 것이다.

a) 부패 척결에 대한 각자의 약속을 충실히 이행하고, 모든 부패 관행에 대해 무관용 
문화와 법률을 강화한다. 여기에는 재정 투명성 강화, 독립적인 감독기구의 강화, 내부 고발자에 대한 보호 확대 등의 노력이 포함된다.

b) 돈세탁 방지 조치를 강화하고, 탈세 관행에 대처하고, 불법 자산의 추적, 동결 및 회수를 위한 국가 및 국제 정책, 법체계 및 제도적 장치를 강화함으로써 불법 자금 의 흐름을 척결하기 위한 개별 노력을 가속화한다. 여기에는 효과적인 국제협력을 촉진하는 법 제정과 관행 이행이 포함된다.

\section{기후변화 재원}

34. 중기적인 측면에서 볼 때 기후변화 재원이 크게 증가할 것으로 예상된다. 우리는 동 재원이 새로운 기회와 도전을 가져올 것임을 인지하고, 기후변화 재원과 보다 포괄적 인 개발협력을 위한 우리의 접근법 전반에서 일관성과 투명성, 예측가능성을 증진하 기 위해 노력할 것이다. 여기에는 다음 사항을 포함한다.

a) 개발도상국들의 전반적인 국가 개발계획의 필수적인 부분으로써 국가의 기후변화 정책과 계획을 지속적으로 지원하고, 적절한 경우, 개발도상국의 시스템을 통해 이 러한 조치들이 투명한 방식으로 재원을 확보하고, 전달되고, 점검되도록 한다.

b) 기후변화 활동에 참여하는 주체들과 함께 개발효과성에서 얻은 교훈을 지속적으로 공유하고, 기후변화 재원의 전달 과정에서 얻은 혁신이 보다 포괄적인 개발협력에 기여하도록 한다.

\section{앞으로 나아갈 길 : 새천년개발목표를 향한, 그리고 이를 넘어선 진보를 위한 파트너십}

35. 우리는 원조효과성에 관한 파리선언 및 아크라 행동계획에 명시된 약속에 더하여, 부 산총회에서 합의된 약속과 행동계획이 성과를 거둘 수 있도록 상호 책임을 질 것이 다. 동 목표를 달성하기 위해 우리는 다음 사항을 이행할 것이다.

a) 개별 개발도상국에서, 협력의 효과성과 개발 프로세스를 개선하기 위한 우리 노력 의 진전상황을 점검하고 상호 책무성을 증진하는 국별 개발 수요와 우선과제에 기 반을 둔 프레임워크에 합의한다. 우리가 합의한 이러한 프레임워크와 지표 및 목표 들은 개별 국가의 구체적인 상황과 수요에 맞출 것이며, 각국의 원조 및 개발 정책 을 바탕으로 할 것이다. 또한 이러한 활동 결과를 공개할 것이다.

b) 2012년 6월까지 약속 이행에 대한 진전 상황을 지속적으로 점검하고, 이에 대한 국 제적, 지역적 이행 책무성을 제고할 수 있는 선별되고, 적합한 지표와 목표에 합의 할 것이다. 개발도상국 주도의 이니셔티브에 기반을 두고, 기존 원조효과성 원칙에 대한 점검 경험을 기반으로 한다. 우리는 Post-MDG 프레임워크의 맥락에서 이러한 
조치를 검토할 것이다. 우리는 정기적으로 이러한 활동 결과를 발표할 것이다.

c) 개발효과성 개선 노력의 진전 상황을 점검하고 그 영향을 평가하는 역량을 강화하 는 개발도상국 주도의 이니셔티브를 지원한다.

36. 우리는 협력을 강화하고 공동의 목표와 차별화된 행동을 유지하기 위해서는 글로벌 차원의 포괄적인 대화 노력, 상호학습 및 책무성과 함께 지속적인 고위급 정치적 지 원이 필요하다는 사실을 인지한다. 지역기구들은 현장에서의 이행을 지원하고 범세계 적 노력과 수원국의 우선과제를 연계하는데 있어서 중요한 역할을 할 수 있고, 그러 한 역할을 해야 한다. UN 개발협력포럼(Development Cooperation Forum)도 부산총 회의 합의사항을 이행하는데 역할을 할 수 있도록 한다. 이러한 목표를 위해서 다음 사항을 이행할 것이다.

a) 새롭고 포괄적인 '효과적인 개발협력을 위한 글로벌 파트너십'(Global Partnership for Effective Development Co-operation)을 구축하여, 정치적 수준에서 약속 이행 을 지원하고 책무성을 갖도록 한다. 동 파트너십은 다양성을 포용하는 열린 플랫폼 을 통해 지식의 교환과 주기적으로 진전사항을 검토하는 포럼을 구축한다.

b) 2012년 6월까지 새로운 파트너십의 가벼운(light) 형태의 운영방안에 대해 합의한 다. 동 방안에는 새로운 파트너십의 구성원, 각료급 인사의 정기적 참여방안, 다른 개발협력 포럼을 보완하고, 연계하는 방안을 포함한다.

c) 원조효과작업반에게 동 결과문서를 승인하는 국가와 개발주체가 참여하는 회의를 개최하여 새로운 글로벌 파트너십 운영방안 및 글로벌 모니터링과 책임을 지원할 지표와 채널을 구축하는데 합의토록 하고, 2012년 6월까지 원조효과작업반과 관련 조직 활동의 점진적 종료를 준비하도록 요청한다.

d) $\mathrm{OECD}$ 와 유엔개발계획(United Nations Development Programme)에게 지금까지의 상호협력과 각자의 역할 및 비교우위 영역을 바탕으로 글로벌 파트너십이 효과적 으로 기능하도록 지원할 것을 요청한다. /끝/ 